\title{
Religion Education with Beyond the Wall Model to Promote Tolerant Behavior in The Plural Society of Indonesia
}

\author{
Imron Arifin, Aan Fardani Ubaidillah \\ Administrative Education Department, Faculty of Education \\ Universitas Negeri Malang \\ Malang, Indonesia \\ imron.arifin.fip@um.ac.id, afubaidillah@gmail.com
}

\begin{abstract}
One of the characteristics of religion education is endeavoring to establish and develop individual piety and social piety. Individual piety is personal, while social piety always pays attention and cares about the social conditions. In social life, school is one of institutions which represents the social environment and become the agent of social education in shaping the behavior of learners who always have open and tolerant attitudes in building a spirit of brotherhood. The responsibility of education in learning activities can develop the ability to dialogue and seek common ground which shall become the foundation and provision for learners to engage in dialogue with the surrounding reality, especially the reality of diversity. In the context of Indonesia, the models of religion education "beyond the wall" can be an alternative in response to conservative forces (in the wall and at the wall) which only teach the religion-doctrinal inclusive manners. The education and study of religion with beyond the wall model not only show the attitudes of acceptance or dialogue with people of different religions, but also emphasize on the religious attitudes of tolerance and cooperation in building peace, justice, harmony, and active involvement in humanitarian activities.
\end{abstract} plural

Keywords - religion education, beyond the wall model, tolerant,

\section{INTRODUCTION}

Indonesia is a diverse country. The pluralism of Indonesia can be viewed from two perspectives, i.e., horizontal perspective and vertical perspective. According to horizontal perspective, Indonesia has the plurality and diversity of religion, ethnic, regional language, geography, clothing, food, and culture. Whereas according to vertical perspective, Indonesia has the diversity of the levels of education, economy, housing, job, and socio-culture [1], [2]. Furthermore, the plurality of Indonesia in terms of geography and socio-culture shall be discussed in more detail. Geographically, Indonesia is the largest archipelago in the world. In 1987, exactly through the Conference on the Standardization of Geographical Names (United Nations Conference on the Standardization of Geographical Names/UNCSGN) in Montreal, Canada, for the United Nations (UN), Indonesian Government reported that Indonesian islands have increased from 13,667 into 17,508 islands.
Then, the data which has been equipped with a list of the island's names to be asked would be delivered back to the United Nations. The data of December 2010 reported that only 6,900 of the islands with a name which have been standardized in accordance with international standards of 17,504 islands scattered across the territory of Indonesia, while the rest still do not have a recognized name internationally [3].

In terms of socio-culture, Indonesia has 726 regional languages with 456 successfully mapped regional languages, in which over 1 million speakers for 13 languages, as stated by Head of the Language Yogyakarta on Language Congress IX in Jakarta [4] that there are 746 regional languages, and 17,508 islands in Indonesia, in which 7,870 islands have been named, with as many as 1,128 ethnic groups. It lead to the fact of increased plurality as released by Central Bureau of Statistics in 2010 [4], which indicated that Indonesia has 1,340 ethnic groups: Java with $41.7 \%$ (86.012 million), Sunda with $5.4 \%$ (31.765 million), Malay with $3.4 \%$ (7.7 million), Madura with $3.3 \%$ (6.80 million), and Batak with (3.0\% (6.188 million) of the total 206 million.

In one side, this diversity is a worthy and potential asset to support the interests of development and the prosperity of the nation, while on the other side it has some potential social conflicts which can threaten the state integrity (disintegration). It is because diversity is often exploited and misinterpreted by a certain person or group to fuel the tension between ethnic, religion, and race groups [5]-[7]. Some of the recorded conflicts which have occurred in Indonesia with the backgrounds of different tribe, religion, race, group are the conflicts in Ambon and Poso (conflict between Islam and Christianity), in Sanggau Ledo, Sambas and Sampit (conflicts between Dayak and Madura ethnics) and on May 1998 (the political conflict of anti-Chinese sentiment).

The cases mentioned above were only a few from many cases which have not known by the public. They were not published by mass media, arguing that the issues were not "feasible" enough due to other political issues in the country which were much more attractive to the mass media in general. According to the theory of journalism, the most common public issues raised by the mass media are the issues of 
violence, political conflict, and sex. It is due to the more profitable market share [8].

Therefore, a serious, systematic and comprehensive thinking is needed to minimize conflict, and on a larger scale to build a collective awareness of the reality of diversity in the society. This kind of awareness shall be good for cultural tolerance.

One factor which is believed by society in human survival is education. Religion education is related to the process of education in the formal and non-formal institutions. A multicultural vision of religion education is a strategic step to provide the insight to Indonesian people, especially the young generation, so that they are more understanding and capable of embodying and implementing a multicultural discourse in the form of social interaction in everyday life [9], [10]. The tolerance enhancement in schools which is constituted with noble characters is directly related to religion education. Therefore, schools have an important role to inculcate the attitude of religious tolerance, especially in schools with heterogeneous students.

\section{DisCuSSION AND ANALYSIS}

\section{A. Status of Religion in the National Education System}

Religion has an important position in the national education. There are five jurisprudential arguments associated with the position of religion in education in Indonesia. First, the national education goals as set forth in the Law of the Republic of Indonesia No. 20/2003 on National Education System [11], article 3: "National education serves to develop the ability and character development and civilization of the nation's dignity in the context of educating the nation aimed at developing students' potentials in order be a man of faith and fear of God Almighty, noble, healthy, knowledgeable, skilled, creative, independent, and become citizens of a democratic and responsible."

Second, the development of the curriculum. The curriculum is prepared in accordance with the level of education within the framework of the Republic of Indonesia with respect to: (a) the increase of faith and piety (taqwa), (b) the enhancement of noble character, (c) the increase in the potential, intelligence, and interests of the learners, (d) the diversity of local potential and environment, (e) the demands of regional and national development, (f) the science, technological and art development, (g) the religion development, (h) the dynamics of global development, (i) the national unity and values (Law of the Republic of Indonesia No. 20/2003 on National Education System, article 36).

Third, religion education is an integral part of the renewal and development of national education. "Renewal of the national education system requires a particular strategy. National education development strategy in this legislation include: (1) the implementation of religion education and good character, (2)... "(a general description of Law of the Republic of Indonesia No. 20/2003 on National Education System).

Fourth, an institutional religion education. In religion education at the national education system, government and/or community groups can organize religion education which serves to prepare students to be the members of society who understand and practice the values of their religion and/or become theologians. (Law of the Republic of Indonesia No. 20/2003 on National Education System, article 30, paragraph 2).

Fifth, religion education is a compulsory subject in the curriculum of elementary, middle and high schools. "(1) The curriculum in primary and secondary education shall contain: (a) religion education, (b) civic education, (c) language, (d) mathematics, (e) science, (f) social science, (g ) arts and culture, (h) physical education and sport, (i) the skills / vocational, and (j) local content. (2) The curriculum of higher education shall contain: (a) religion education, (b) civic education, (c) language." (Law of the Republic of Indonesia No. 20/2003 on National Education System, article 37 paragraph 1-2).

Having related to the curriculum, religious subjects have equal footing with other subjects, as stated in Government Regulation No. $19 / 2005$ and No. 32/2013 on National Education Standards [12], article 6: "The curriculum for this kind of general, vocational and special education on the level of primary and secondary education consists of: (a) a group of religious subjects and noble character, (b) a group of subjects in nationality and personality, (c) a group of subjects in science and technology, (d) a group of subjects in aesthetics, and (e) a group of subjects in physics, sports, and health."

\section{B. Religion Education System In Indonesia}

Religion education in Indonesia is defined as education which provides knowledge and forms the attitudes, personality and skills of the students in the practice of their religion, which is carried out at least through the subjects in all courses, levels and types of education (Government Regulation No. 55/2007 on Religion education and Religious Education, article 1, paragraph 1) [13].

Religion education has a purpose and function to establish the human faith and fear to God Almighty and the good character of Indonesian people, and capable of maintaining peace and harmony and the internal relations between religious communities in Indonesia. "...while education aims to develop the capacity of students to understand, appreciate and practice the values that harmonize religion mastery in science, technology and art" (Government Regulation No. 55/2007 on Religion education and Religious Education, article 2, paragraph 1-2) [13].

The implementation of the religious education has been stipulated in the learning system, as written in Law of the Republic of Indonesia No. 20/2003 on National Education System, article 12, paragraph 1 that "All students at any educational institution entitled to: (a) receive religion education in accordance with religious espoused and taught by educators of the same religion ... " (Law of the Republic of Indonesia No. 20/2003, article 12/1)."...teachers and/or religious teacher correligionists learners facilitated and/or provided by the government and/or regional governments according to the needs of the education unit ... ". 
Furthermore, in general, religion education is also stipulated in Government Regulation No. 55/2007 on Religion education and Religious Education, section 5, which described: (a) religion education is conducted in accordance with the National Education Standards; (b) religion education is taught according to the stage of the psychological development of the learners; (c) religion education encourages students to obey the teachings of their religion in everyday life and make religion as the foundation of ethics and morality in their private, family, community, nation, and state lives; (d) religion education embodies the harmony and respect among fellow believers who adopt or against other religions; (e) religion education builds the mental attitude of learners to act and behave in honest, trustworthy, disciplined, hard-working, independent, confident, competitive, cooperative, sincere and responsible manners; (f) religion education fosters the critical, innovative, and dynamic attitudes of the learners to enhance their competences in the area of science, technology, art, and/or sport; and (g) religion education is held in an interactive, inspiring, fun, challenging, and encouraging creativity and independence, as well as the motivation for a successful life.

\section{Tolerant behavior}

Tolerance is an understanding toward a mistake rather than on a difference. A difference is not a mistake because it is unavoidable. The obstacles in building tolerance is the lack of knowledge about the differences which cause people to become self-centered and arrogant toward their relatives, friends, neighbors, and community. For people with the lack of knowledge, their attitude and action are only based on prejudice which should be avoided, because it can damage human relations. Thus, knowledge about the differences is pivotal for a peace and prosper life.

Nevertheless, it should be noted that tolerance must not override the rights and obligations. There should be a mutual respect. Rights and obligations must be in balance. God has created human beings in different conditions. Everyone is equal before the Lord in spite of different ethnic, race, religion, and economy status. Tolerance behavior can provide benefits, e.g., avoid fragmentation, strengthen relationships, build unity, and strengthen religious diversity [14], [15]. There are several examples of tolerance, e.g., do mutual respect, do not disturb and participate in a positive way. This understanding of multiculturalism is provided by education in schools [16], [17].

It is undeniably that schools provide the possibility of enhancing the base of knowledge and life experiences of students to appreciate diversity and plurality. Mistakes tolerance is understood as a form of passive ignorance (passive indifference) toward indifference which is not positive, passive apathetic or unwilling to offer any judgment against others because of the passion and commitment. Before building a tolerant behavior the person will still provide an assessment, either positive or negative, to the opinions of others with moral commitment and self-conception. Therefore, tolerance does not mean indifference, thus criticism is polite, and empathetic in dialogue [18]. Everyone should respect the differences as well as the need to critically correcting the understanding of themselves and others in the process of looking for a better understanding. This concept is called "critical tolerance" which stands on the principle of "critical interactions".

\section{Religion education with Beyond The Wall Model for Tolerant Behavior}

Tolerance in fact has been confirmed as part of the nation's 18-character value which is central to the implementation of character education. Precisely, in order to further strengthen the implementation of character education, 18 values have been identified from religion, Pancasila, culture, and the national education goals, which are: (1) Religious, (2) Honest, (3) Tolerant, (4) Discipline, ( 5) Hard working, (6) Creative (7) Independent, (8) Democratic (9) Curious, (10) Nationalistic, (11) Patriotic, (12) Appreciative toward achievement, (13) Friendly/Communicative, (14) Peaceful, (15) Like to read, (16) Environmental (17) Social, and (18) Responsible (Center for Curriculum in Head of Research and Development - Ministry of National Education, 2011: 8).

In pluralistic and multicultural society like Indonesia, diversity becomes the principal dimension to be cultivated. This can be done in integrative manners through various subjects in different courses and levels of education. Religion and moral education as one of the principal subjects in the education system of school are certainly facing a formidable challenge to build a Bhineka Tunggal Ika (Diversity in Unity) learning system. This is not apart from the rampant cases of violence in the name of religion today, which generally target other religious groups.

In such conditions, religion education can be the basis of a review and analysis of a numbers of socio-humanitarian problem which occur in pluralistic society like Indonesia. Teaching religion education according to Seymour [19] should use a model which allows the formation of interrelation acceptance or tolerance among students. This could happen if religion education not only teach the knowledge of one's own religion, but also others' religion.

Whereas Christiani [20], in her research found three models of the education and study of religion, i.e., the model in the wall, at the wall, and beyond the wall. First, in the wall model. This model emphasizes more on the education and study of one's own religion, and does not teach any other religion. The teaching about other religions is more likely to reveal the negative sides and is less proportionate. Other religions are placed as a threat, suspected, and do not bring truth and salvation. In other words, this model teaches an exclusive religion against the reality of religious diversity around.

Second, at the wall model. This model prioritizes the education and study of not only one's own religion, but also others' religion through dialog. This model leads to the perceptions and attitudes of mutual understanding and getting attracted to articulate the truth of each religion in order to find the similarities and not mutually polemic. In this model, an inclusive attitudes toward the reality of religious diversity begin to find its form.

Third, beyond the wall model. The education and study of religion with this model not only shows the attitudes of acceptance or dialogue with people of different religions, but 
also emphasizes on the religious attitudes of tolerance and cooperation in building peace, justice, harmony, and active involvement in humanitarian activities.

Of the three models of religion education and study offered above, the third model includes the acceptance of social aspects without leaving the aspects of deity, which must be directive in each individual for his/her religious belief, especially for the people in heterogeneous schools. Thus, it should be able to create atmosphere which is more open on the understanding of their own religion. In the assessment of Nuryatno [14], the religion education in the context of pluralistic Indonesia, especially Islamic religion education, it was found to practice the dominant in the wall model. He hoped that Islamic religion education would shift into at the wall model, and beyond the wall model. It is for the sake of Muslim students to have an understanding, open and proportional attitude in view of differences in beliefs.

In certain moments the models at the wall and beyond the wall state that the common enemy is not the differences in ethnicity, religion, race, and class, but violence, humiliation, poverty, injustice, corruption and the like. Most of religion education in schools is ideological-authoritarian. There are no possibility of dialogue there. The debates of critical issues in religions are never presented in a transparent manner to have common ground.

Religion education is textually-formalistic taught so that the response given to the reality of pluralism becomes so stiff and helpless. Conversely if the study of religion is trying to grow criticism and appreciation for one's own religion or faith of others, it even can be considered misleading. Further in the assessment of Noer [21], there is suppression of religion education during the process of the transfer of religious knowledge to the students and not the transformation process of nobleness religious values to students in order to be a strong and noble person.

This process is more common in the religion education which "teach", not "educate" [18], [22]. Abdullah [23], also stated that the practice of religion education showed that the education and study of religion generally still more emphasize on the safety of individuals and the group itself than others' beyond their group. The vision and mission of religion education seem still characterized and dominated by the basic assumptions of classical-scholastic paradigm which underline the confidence and the belief that "social security" and "group safety" are determined by and dependent on "individual salvation". In other words, individual salvation is much more fundamental and important than the social safety. The discussion on religion education with beyond the wall model to promote tolerant behavior in a plural society can be described in the Fig. 1.

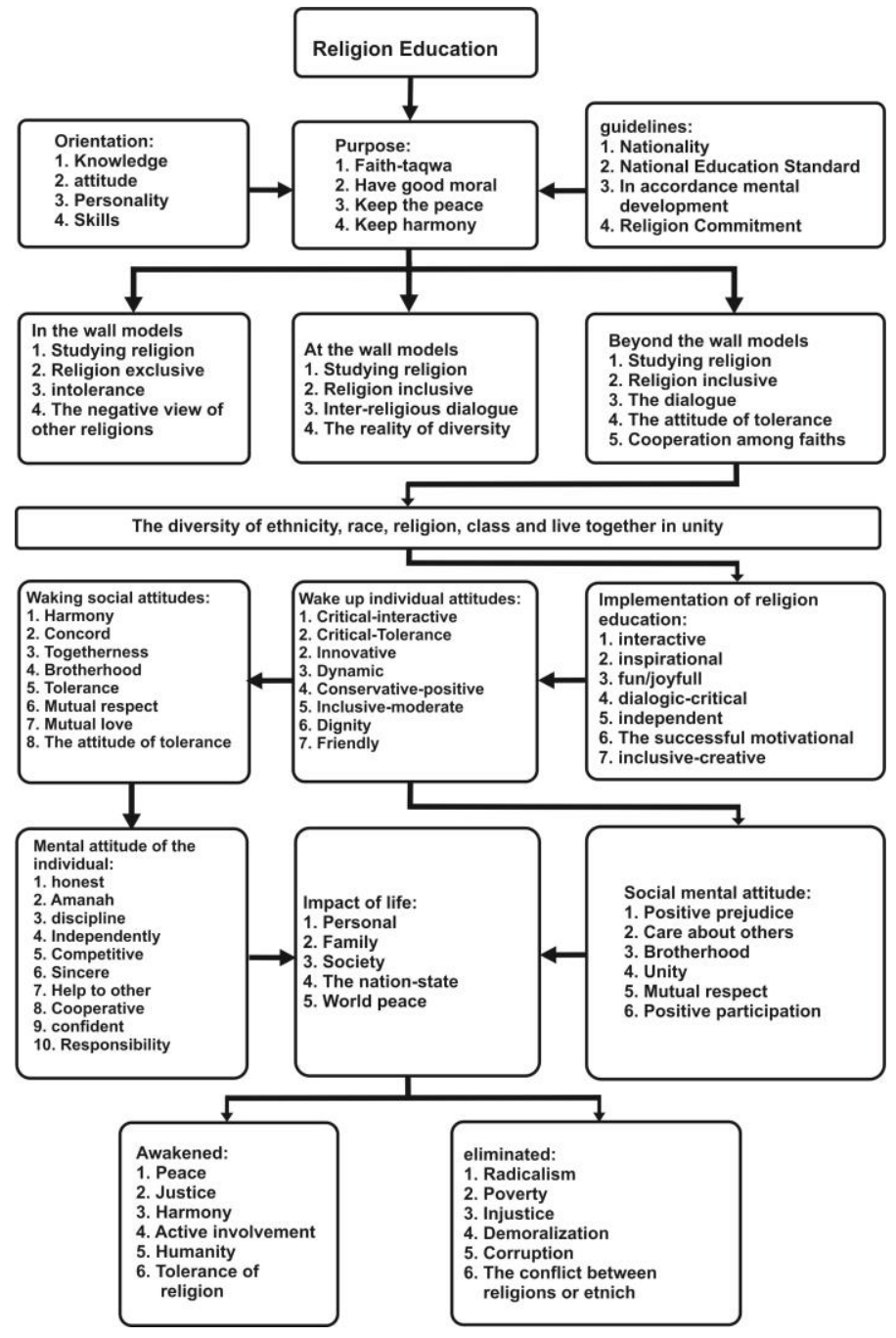

Fig. 1. Religion education with beyond the wall model for tolerant behavior

\section{CONCLUSION}

In cultivating attitudes as described above, education is the most appropriate, especially religion education for tolerance and harmony, and sincere appreciation for the reality of the diverse cultural-religious society. Religion education in the national education system can be one of the most effective media for the next generation to make diversity appreciated constructively.

At the very least, religion education is able to give awareness to the public that conflict should not be cultivated. Religion education is also able to offer the possible material and method for curriculum which give the public awareness of the importance of mutual tolerance attitudes of respecting the differences in the religion, race, ethnicity and culture of Indonesia's multicultural society. To be a tolerant person, the plurality of understandings and beliefs should be acknowledged and appreciated without having to justify it all.

In such context, the religion education with beyond the wall model can actually respond to the dynamics of multiculturalism. The education and study of religion with 
beyond the wall model not only show the attitudes of acceptance or dialogue with people of different religions, but also emphasize on the religious attitudes of tolerance and cooperation in building peace, justice, harmony, and active involvement in humanitarian activities.

Outside the issues of faith, every religion teaches the universal truth of human values. The models of religion education reviewed in this paper are the real attempts to uncover the universality and present them in a form of religiondialogical learning which enables people across religions to mutually learn from each other. The hope is the formation of tolerance and pro-social inter-faith.

However, the study in this paper is still limited and conceptual. The appropriateness and effectiveness of the models of religion education, especially beyond the wall, can be developed further by subsequent researchers through experimentation, research and development ( $R \& D)$, action research, qualitative research and other methods. Researches can be conducted in plural and multicultural school/community with a more in-depth study, of course with an engaging restrictions.

\section{REFERENCES}

[1] M. T. Hasan, "Islam dan Pendidikan Multikultural," in National Seminar of "Membangun Peradaban Masyarakat yang Bermartabat dan Berkarakter Unggul melalui Pendidikan Multikultural.," 2014.

[2] N. Naim and A. Sauqi, Pendidikan Multikultural Konsep dan Aplikasi. Yogyakarta: Ar-Ruzz Media, 2008.

[3] A. Ardiansyah, "Pembakuan Nama Pulau di Indonesia Sebagai Upaya untuk Menjaga Kedaulatan Negara Republik Indonesia,” Pandecta, vol. 6, no. 2, pp. 117-127, 2011.

[4] Z. Zamzani, "Eksistensi Bahasa Indonesia dalam Pendidikan Berbasis Keragaman Budaya,” Dialekt. J. Bahasa, Sastra, dan Pendidik. Bhs. dan Sastra Indones., vol. 1, no. 2, pp. 225-244, 2014.

[5] T. Rahardjo, Menghargai Perbedaan Kultural: Mindfulness dalam Komunikasi antar Etnis. Yogyakarta: Pustaka Pelajar, 2005.

[6] I. Masduqi, "Pengantar Fanatisme dan Toleransi," in Berislam Secara Toleran: Teologi Kerukunan Umat Beragama, Bandung: Mizan, 2011.

[7] I. Masduqi, Berislam Secara Toleran: Teologi Kerukunan Umat Beragama. Bandung: Mizan. Bandung: Mizan, 2011.

[8] C. Mahfud, Pendidikan Multikultural. Yogyakarta: Pustaka Pelajar, 2009.

[9] Z. Misrawi, Pandangan Muslim Moderat: Toleransi, Terorisme dan Oase Perdamaian. Jakarta: Penerbit Buku Kompas, 2010.
[10] I. Arifin, "Islam Nusantara: Sejarah, Perkembangan, dan Kontroversinya," in Proceeding of the National Seminar of "Islam Nusantara Meneguhkan Moderatisme dan Mengikis Ekstrimisme dalam Kehidupan Beragama, 2016.

[11] Direktorat Utama Pembinaan dan Pengembangan Hukum Pemeriksaan Keuangan Negara BPK RI, "Undang-undang Nomor 20 Tahun 2003," Jaringan Dokumentasi dan Informasi Hukum Badan Pemeriksa Keuangan Republik Indonesia, 2003. [Online]. Available: http://jdih.bpk.go.id/?p=39295. [Accessed: 13-Sep-2016].

[12] Head of Government of the Republic of Indonesia, Government Regulation of the Republic of Indonesia on Education Standard. Indonesia, 2013.

[13] Head of Government of the Republic of Indonesia, Government Regulation of the Republic of Indonesia on Religion education and Religious Education. Indonesia, 2007.

[14] M. A. Nuryatno, "Islamic Education in a Pluralistic Society," AlJami'ah, J. Islam. Stud., vol. 49, no. 2, pp. 411-431, 2011.

[15] I. Arifin, "Da'wah Management of The Wali Songo Socio-CulturalReligious Heritage of Nusantara Islamic in Indonesia," in Proceeding of The 1st International Conference on Humanities and Social Sciences, 2016.

[16] T. Sumartana, Pluralisme, Konflik, dan Pendidikan Agama di Indonesia. Yogyakarta: Institut DIAN/Interfidei, 2001.

[17] A. K. . Sonhadji, Membangun Peradaban Bangsa dalam Perspektif Multikultural: Potensi Indonesia menjadi Negara Besar. Malang: UM Press, 2015.

[18] M. H. Ay, I. Arifin, and A. Suriansyah, "The implementation of the Islamic Schools resources total quality management In Banjarmasin, Indonesia (A Multicase Study at State Islamic Primary School of Pemurus Dalam, State Islamic Middle School of Mulawarman, and State Islamic High School of Banjarm,” J. Soc. Sci., vol. 6, no. 1, pp. 125138, 2017.

[19] J. Seymour, Educating Christians: The Intersection of Meaning, Learning, and Vocation, With Marga. Nashville: Abingdon Press, 1993.

[20] T. K. Christiani, "Blessed are The Peacemaker: Christian Religiuos Education for Peacebuilding in The Pluralistic Indonesian Context," Boston College, 2005.

[21] K. A. Noer, "Pluralisme dan Pendidikan di Indonesia: Menggugat Ketidakberdayaan Sistem Pendidikan Agama," in Pluralisme, konflik, dan pendidikan agama di Indonesia, T. Sumartana, Ed. Yogyakarta: Institut DIAN/Interfidei, 2001.

[22] I. Arifin, "Pendidikan Multikultural Perspektif Keagamaan dan Kultural," in Sunandar, A. Prof. Son Sang Pendidik Multikultural, Malang: Intelegensia Media, 2015, p. 77.

[23] M. A. Abdullah, "Pengajaran Kalam dan Teologi dalam Era Kemajemukan di Indonesia: Sebuah Kajian Teori dan Metode," in Pluralisme, konflik, dan pendidikan agama di Indonesia, T. Sumartana, Ed. Yogyakarta: Institut DIAN/Interfidei, 2001. 